\title{
Clostridium thermobutyricum sp. nov., a Moderate Thermophile Isolated from a Cellulolytic Culture, That Produces Butyrate as the Major Product
}

\author{
JUERGEN WIEGEL, * SEUNG-UK KUK, † AND GERT W. KOHRING \\ Department of Microbiology and Center for Biological Resource Recovery, \\ University of Georgia, Athens, Georgia 30602
}

\begin{abstract}
A new moderately thermophilic clostridium, Clostridium thermobutyricum, was isolated from cellulolytic enrichment cultures inoculated with horse manure. This organism forms subterminal spores, and the sporangium is not swollen. From glucose, the organism produces butyrate, $\mathrm{CO}_{2}$, and $\mathrm{H}_{2}$ and minor amounts of acetate and lactate. Yeast extract is required for good growth. The temperature range for growth is between 26 and $61.5^{\circ} \mathrm{C}$. The pH range is between 5.8 and 9.0. The guanine-plus-cytosine content is 37 mol\%. The type strain is $C$. thermobutyricum JW171K (= DSM 4928).
\end{abstract}

During the enrichment and isolation of cellulolytic thermophilic anaerobes, butyrate frequently is encountered as a fermentation product. For more than two decades, it was thought that butyrate was an end product of the cellulose degrader Clostridium thermocellum $(4,7,12)$. However, when pure cultures were finally obtained, it was found that the butyrate was formed by contaminating organisms. Thus, pure cultures of the known cellulolytic thermophilic clostridia, $C$. thermocellum and Clostridium stercorarium, do not produce butyrate. In 1949, Enobo (5) described another thermophilic cellulose degrader, which he named "Clostridium thermocelulaseum." From his cellulolytic enrichment culture he also isolated a butyrate-forming glycolytic organism (5). Unfortunately, neither of his cultures is extant. The $\mathrm{pH}$ optimum of the cellulolytic strain of Enebo was above pH 8.0. We tried to isolate such an organism by using various soil and compost samples as inocula. Only the sample from horse manure produced an enrichment culture which degraded cellulose quickly and formed butyrate as the major product. After several dilution steps, the enrichment culture contained two organisms. One was a cellulolytic clostridium which produced the drumstick type of sporangium typical of $C$. thermocellum. The second clostridium formed central to subterminal spores with little or no swelling of the cells. We present here a formal description of this organism, a new Clostridium species that produces butyric acid as the major fermentation product under moderately thermophilic growth conditions.

\section{MATERIALS AND METHODS}

Isolation and culture conditions. Samples ( 2 to $10 \mathrm{~g}$, wet weight) of horse manure from a manure pile at the University of Georgia horse stable and from private horse stables were inoculated into $50-\mathrm{ml}$ portions of reduced medium in $150-\mathrm{ml}$ serum bottles (Wheaton 400 brand borosilicate glass; Fisher Scientific Co., Pittsburgh, Pa.). These enrichment cultures were incubated at 59 to $60^{\circ} \mathrm{C}$. The medium contained (per liter of distilled water) $0.9 \mathrm{~g}$ of $\mathrm{KH}_{2} \mathrm{PO}_{4}, 3.6 \mathrm{~g}$ of $\mathrm{Na}_{2} \mathrm{PO}_{4} \cdot 7 \mathrm{H}_{2} \mathrm{O}, 0.5 \mathrm{~g}$ of $\mathrm{NH}_{4} \mathrm{Cl}, 0.5 \mathrm{~g}$ of $\left(\mathrm{NH}_{4}\right)_{2} \mathrm{SO}_{4}, 0.18 \mathrm{~g}$

\footnotetext{
* Corresponding author.

$\dagger$ Present address: Department of Agricultural Engineering, Texas A \& M University, College Station, TX 77840.

$\ddagger$ Present address: Fachbereich Biology, University of Regensburg, Regensburg, Federal Republic of Germany.
}

of $\mathrm{MgCl}_{2} \cdot 6 \mathrm{H}_{2} \mathrm{O}, 0.05 \mathrm{~g}$ of $\mathrm{CaCl}_{2}, 5 \mathrm{ml}$ of a trace element solution (7), $0.5 \mathrm{ml}$ of a vitamin solution (modified Wolfe solution [7]) $0.2 \mathrm{~g}$ of $\mathrm{Na}_{2} \mathrm{~S} \cdot 9 \mathrm{H}_{2} \mathrm{O}, 0.2 \mathrm{~g}$ of cysteic acid, $3 \mathrm{~g}$ of yeast extract, and either $10 \mathrm{~g}$ of filter paper (Kimwipes; Kimberly Clarke Corp., Roswell, Ga.) (during early enrichment) or $5 \mathrm{~g}$ of glucose (during purification). The medium was prepared by using the Hungate technique as described previously (11) with an argon atmosphere. After the medium was autoclaved, the $\mathrm{pH}$ was adjusted with anaerobic sterile $\mathrm{NaOH}$ or $\mathrm{HCl}$ to $\mathrm{pH} 8.4$ to 8.6 for enrichment with cellulose. For pure cultures, the $\mathrm{pH}$ was adjusted to $\mathrm{pH} \mathrm{8.0.} \mathrm{The} \mathrm{pH}$ was adjusted periodically during growth. Several serial dilutions were used for enrichment cultures containing glucose as the carbon and energy source. The final isolation of the pure culture was done by repeated isolations of single colonies, using the agar shake roll tube method (11) in medium supplemented with $2.2 \%$ (wt/vol) agar (Difco Laboratories, Detroit, Mich.). Growth was followed by measuring the increase in optical density at $600 \mathrm{~nm}$ with an Ultrospec 4050 spectrophotometer (Pharmacia LKB Biotechnology Inc., Piscataway, N.J.) or a Spectronic 21 colorimeter (Bausch \& Lomb, Inc., Rochester, N.Y.).

Electron microscopy. Cells were negatively stained with uranyl acetate by using the method of Valentine et al. (15) and Beuscher et al. (1). Ultrathin sectioning was done as described by Kellenberger et al. (9). After dehydration, the fixed cells were embedded in the low-viscosity medium of Spurr (14). Sections were collected on carbon-coated Formvar-copper grids and poststained with uranyl acetate (6) and lead citrate (16). Electron micrographs were taken with a Philips model EM 301 electron microscope.

Fermentation products. Volatile and nonvolatile fatty acids, alcohols, $\mathrm{H}_{2}, \mathrm{CO}_{2}$, and glucose were analyzed by using gas chromatography or high-performance liquid chromatography or both, as described previously (2).

Growth studies. Substrate utilization was analyzed at $57^{\circ} \mathrm{C}$ by using the medium described above supplemented with $0.3 \%$ yeast extract and substituting different substrates for glucose. Optical densities were followed, and $\mathrm{pH}$ changes were monitored. Growth in mineral medium (see above) containing $0.3 \%$ yeast extract was used as a control, and the data were corrected by subtracting the value for this background growth. The control cultures (four duplicates) grew to optical densities at $600 \mathrm{~nm}$ between 0.18 and 0.2 , causing $\mathrm{pH}$ changes of 0.5 to 0.6 . Substrate utilization was assumed 
when $\mathrm{pH}$ changes of more than 0.7 or increases in optical density of more than 0.25 were recorded. Assays were performed with duplicate cultures, which were subcultured to obtain the results reported below. Cultures showing marginal growth were repeated. Incubation was for 10 days, except for hemicellulose, pectin, and polygalacturonic acid cultures, which were incubated for 1 month.

The $\mathrm{pH}$ range and optimal $\mathrm{pH}$ for growth were determined in semicontinous cultures by using a 700 -ml fermentor with a $\mathrm{pH}$ control (custom made) and minimal medium supplemented with $0.3 \%$ (wt/vol) yeast extract and $0.5 \%$ (wt/vol) glucose. At each $\mathrm{pH}$, the culture was allowed to adapt for at least five generations before the growth rate was determined at an optical density range between 0.05 and 0.4 . The values reported below are means of least two determinations; one set of data was obtained by adjusting the new $\mathrm{pH}$ from cultures grown previously at a lower $\mathrm{pH}$ value, and another set was obtained from cultures grown previously at a higher $\mathrm{pH}$ value.

Susceptibility to antibiotics was determined by inoculating portions $(5 \%, \mathrm{vol} / \mathrm{vol})$ of a growing culture in the logarithmic growth phase into fresh media containing 5 and $100 \mu \mathrm{g}$ of filter-sterilized antibiotics per $\mathrm{ml}$. Water-insoluble compounds were dissolved in $50 \%$ ethanol or $50 \%$ ethyl acetate in water. The solvents (used and tested at concentrations up to $0.2 \%, \mathrm{wt} / \mathrm{vol}$ ) had no inhibitory effect on the organism. Cultures which exhibited total growth inhibition after 6 days of incubation at $57^{\circ} \mathrm{C}$ were diluted 10 -fold into fresh medium. Subsequent growth was taken as an indication of a bacteriostatic effects by the antibiotic.

Deoxyribonucleic acid isolation and determination of $\mathbf{G}+\mathbf{C}$ content. Deoxyribonucleic acid was isolated by using the method of Whitman et al. (17). The guanine-plus-cytosine $(G+C)$ content was determined after enzymatic digestion and chromatographic separation of the nucleoside bases as described by Whitman et al. (17).

\section{RESULTS AND DISCUSSION}

The following properties indicate that the new isolate is a member of the genus Clostridium: rods forming endospores, strictly anaerobic growth, absence of dissimilatory sulfate reduction, and positive Gram type $(18,19)$ (including testing of polymyxin B-lipopolysaccharide interaction) of cell walls. The positive Gram type differentiates the organism from the gram type-negative sporeforming genus Sporomusa (13). Based on several properties, including morphology, formation of butyrate as the main fermentation product while growing in the thermophilic temperature range, and $\mathrm{G}+\mathrm{C}$ content, we conclude that the new strains are unlike previously described species, and thus we propose the new species described below.

Clostridium thermobutyricum sp. nov. Clostridium thermobutyricum (ther. mo. bu. ty'ri. cum. Gr. adj. thermos, hot; Gr. $\mathrm{n}$. boutyron, butter; N. L. neut. adj. thermobutyricum, referring to the production of butyrate under thermophilic conditions). Vegetative cells from liquid cultures containing $0.3 \%(\mathrm{wt} / \mathrm{vol})$ yeast extract and $0.5 \%(\mathrm{wt} / \mathrm{vol})$ glucose are straight to slightly curved rods which are 0.9 to $1.1 \mu \mathrm{m}$ in diameter and 2.0 to $4.5 \mu \mathrm{m}$ long. Cells appear mainly as single cells, but pairs and longer chains with up to 15 cells are frequently observed (Fig. 1A). In the late logarithmic and stationary growth phases many larger cells (1.6 to $2.1 \mu \mathrm{m}$ in diameter and up to $8 \mu \mathrm{m}$ long) are observed. These large cells are formed regardless of whether the cells sporulate (Fig. 1B). Usually sporulated cells are like the large station-
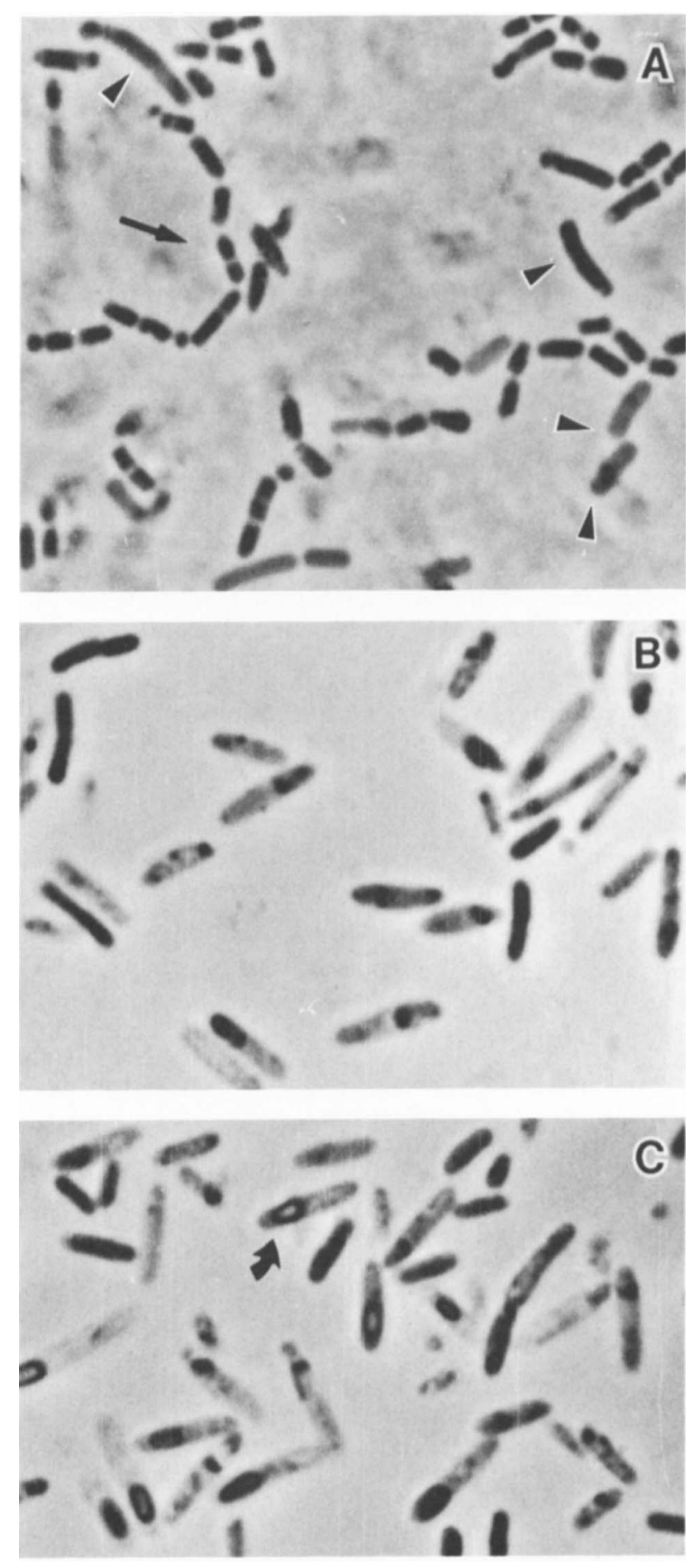

FIG. 1. C. thermobutyricum. (A) Vegetative cells in the logarithmic growth phase. The arrowheads indicate large stationary cells. The arrow indicates a chain of cells. (B) Stationary cells, not sporulating due to $\mathrm{pH}$ control. (C) Sporulating cells with central to subterminal endospores. All magnifications, $\times 3,000$. 

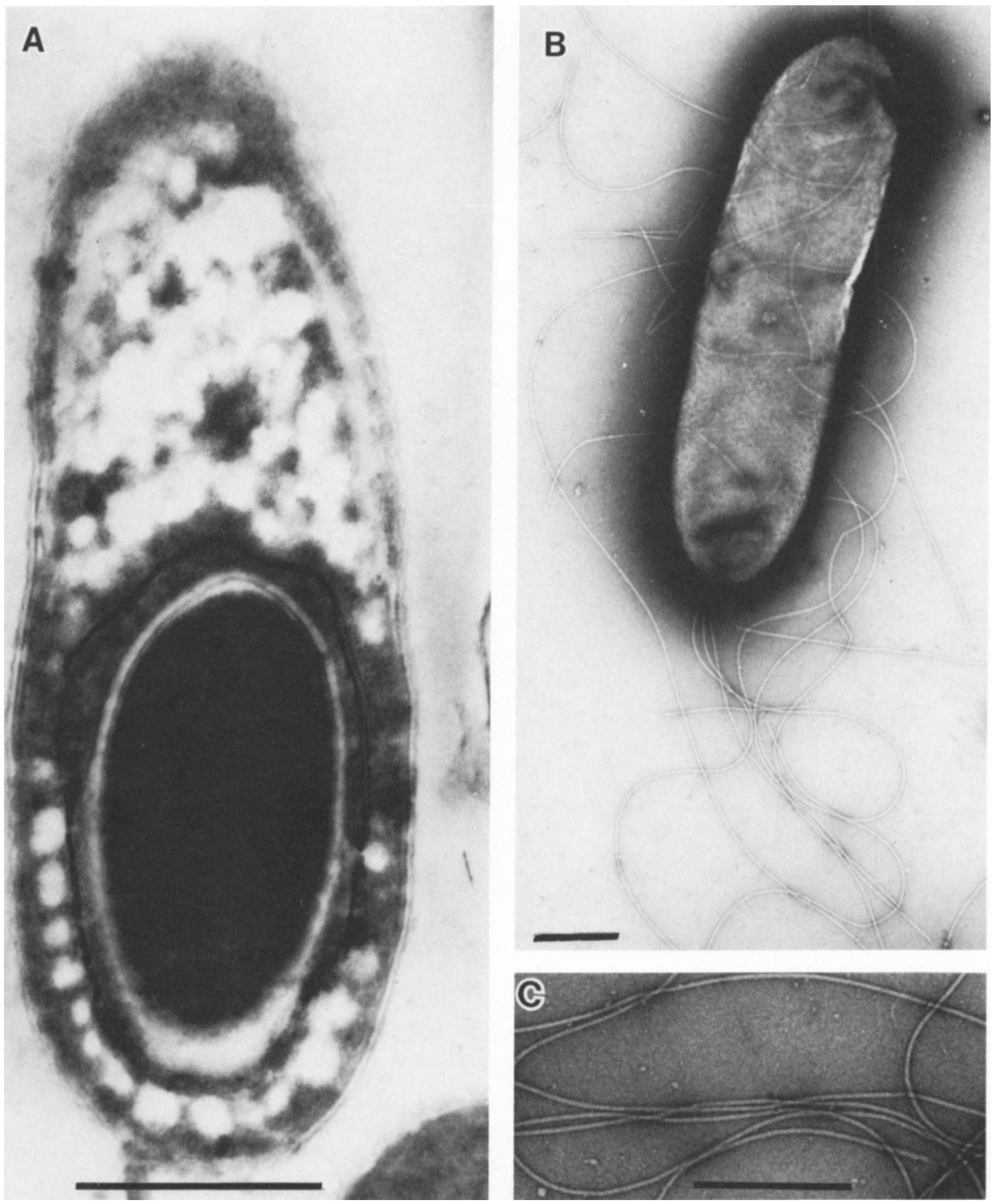

FIG. 2. (A) Ultrathin section of a cell from the stationary growth phase with a subterminal spore and surrounding cell inclusions. (B) Negative staining of a vegetative cell with flagella ( $2 \%$ uranyl acetate). (C) Close-up of flagella. Bars represent $0.5 \mu \mathrm{m}$.

ary cells (Fig. 1C). When sporulation occurs in mid-logarithmic phase, the spore-containing cells are only slightly larger than the other cells.

Sporulation. Sporulation apparently is initiated at $\mathrm{pH}$ values below 6.2. The spores are central to subterminal. More pronounced swelling is observed during early enrichment when the spores are found more in the central parts of the cells. After 3 years of subculturing on medium containing glucose plus yeast extract, the predominant spore position is subterminal, with little or no distension of the cells. In micrographs of ultrathin sections of sporulated cells, the spores usually are surrounded by inclusion bodies, which are assumed to be $\beta$-hydroxybutyrate granules (Fig. 2A). These granules also are seen in stationary-phase cells that do not sporulate.

Flagella. Although the cells are peritrichous (Fig. 2B), they do not exhibit pronounced motility. However, a tumbling motion beyond Brownian movement is observed during the 

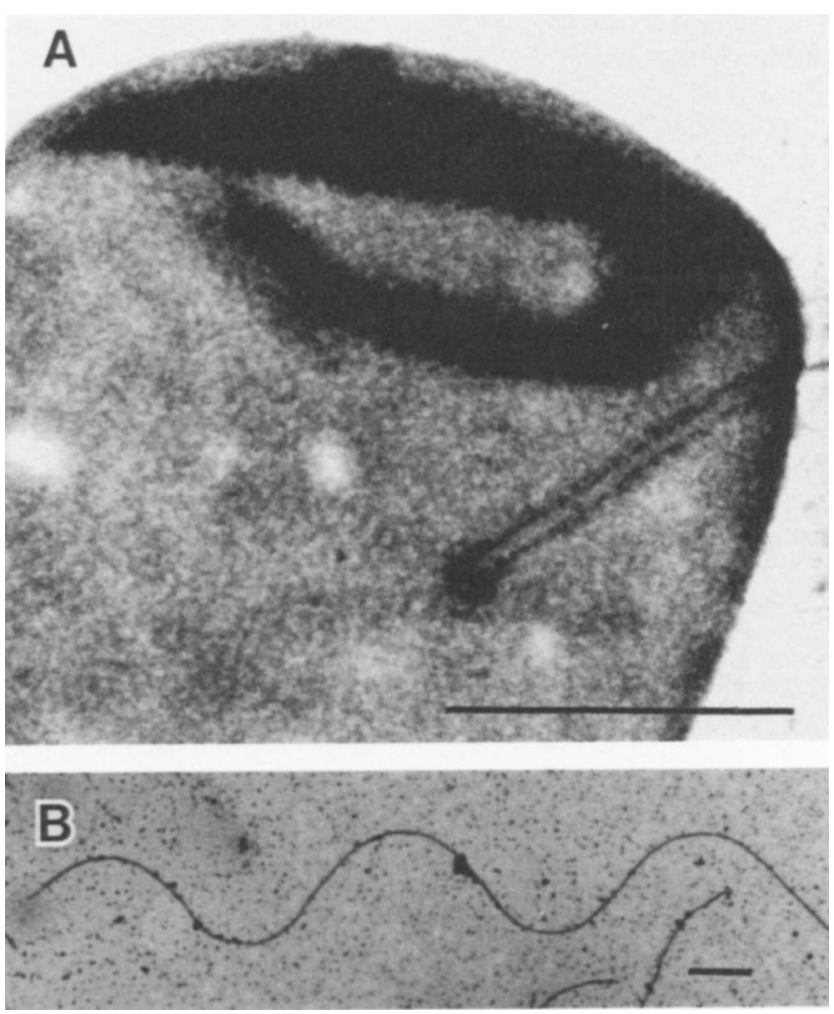

FIG. 3. Negative staining of cell fragment (envelope) showing no regular pattern of outer protein layer (A) and flagellum (B). Bars = $0.5 \mu \mathrm{m}$.

early logarithmic growth phase. Cells have 5 to 12 flagella of the $25.0-\mathrm{nm}(250-\AA)$ type with a wavelength of 2 to $3 \mu \mathrm{m}$ (Fig. 2). Pili or fimbriae are not observed.

A regular pattern of an outer protein layer is not observed on whole cells, cell envelope fragments, or ultrathin sections. However, in micrographs of ultrathin sections (Fig. 3) proteinlike structures are seen on fragments of the cell envelope and fractions of an additional layer.

Gram stain reaction and Gram type. The Gram stain reaction usually is negative. Cells staining gram positive occasionally are found during the very early logarithmic growth phase, between 1 and $2 \mathrm{~h}$ after inoculation. Micrographs of ultrathin sections show a slightly atypical grampositive type of cell wall. The polymyxin B-lipopolysaccharide test (19) gives no indication of the presence of lipopolysaccharides. Such behavior also is known for some other clostridia (19). Thus, $C$. thermobutyricum is classified as Gram type positive as defined by Wiegel (18) and Wiegel and Quandt (19). The organism has an m-Dpm-direct cell

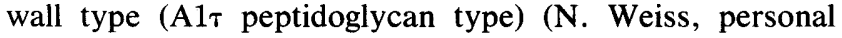
communication).

Morphology. Colonies in agar shake roll tubes are white to creamish and irregularly circular with lobate margins. Colonies on agar surfaces are irregularly circular with matte surfaces. Colonies that are 3 weeks old turn brown, but do not produce water-soluble pigment.

Growth requirements. Anaerobic. No growth is observed when rezasurin in the medium is slightly pink. The exposure of vegetative cells to air for more than 10 min during transfer frequently causes prolonged lag phases or even no growth. Yeast extract is required for growth and cannot be replaced

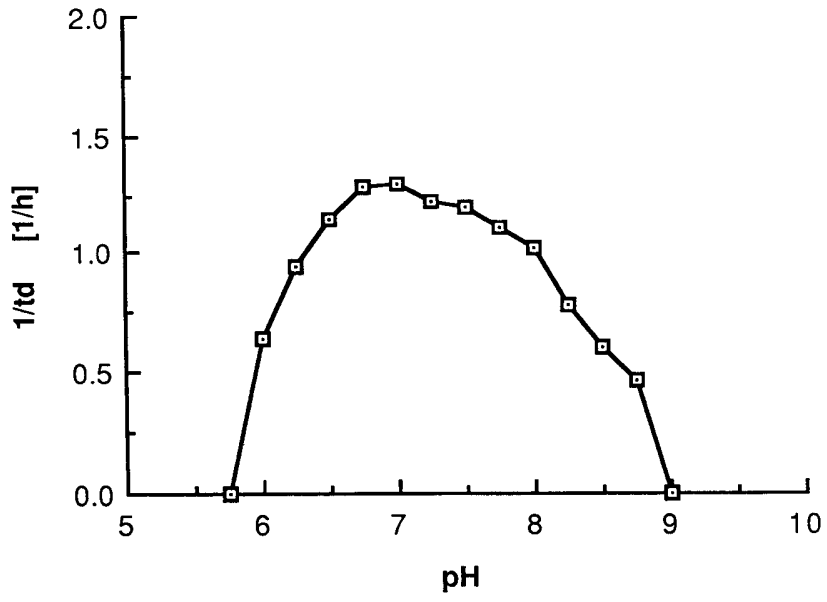

FIG. 4. Effect of $\mathrm{pH}$ on doubling times (td) during growth in $\mathrm{pH}$-controlled semicontinous cultures. See Materials and Methods for details.

with peptone, tryptone, casein, or a mixture of vitamins (Wolfe vitamin solution).

The $\mathrm{pH}$ range for growth is $\mathrm{pH} 5.8$ to 9.0, with an optimum between $\mathrm{pH} 6.8$ and 7.1. (Fig. 4). The doubling time at the optimal pH and temperature is 45 to $50 \mathrm{~min}$. At pH 8.5, a value encountered in fresh horse manure piles, the doubling time is about $90 \mathrm{~min}$, which is faster than the doubling times of the thermophilic cellulose degraders. The marginal temperature data are as follows: maximum temperature, $61.5^{\circ} \mathrm{C}$; optimal temperature, around $55^{\circ} \mathrm{C}$; and minimum temperature, $26^{\circ} \mathrm{C}$.

Substrates. The organism grows with $0.3 \%(\mathrm{wt} / \mathrm{vol})$ yeast extract alone but not with peptone, tryptone, or casein alone. Moreover, in the presence of $0.3 \%$ yeast extract, these additives do not stimulate growth. In the presence of $0.3 \%$ yeast extract, the following substrates lead to an increase in growth (increase in optical density at $600 \mathrm{~nm}$ of 0.4 to $0.8 \mathrm{u}$ above background growth on medium containing yeast extract; see above) and acidification of the medium (decrease in $\mathrm{pH}$ of 0.8 to $1.6 \mathrm{u}$ ): monomeric sugars (Dglucose, D-fructose, maltose, D-xylose and D-ribose but not $\mathrm{D}$-arabinose, D-galactose, and D-mannose); dimeric, oligomeric, or polymeric sugars (cellobiose, but not sucrose, D-raffinose, starch, or beech or birch hemicellulose); sugar derivatives (D-glucuronic acid and D-galacturonic acid, but not xylitol, pectin, or polygalacturonic acid); and organic acids (pyruvate, but not succinate, fumarate with or without formate, and malate). Growth is not stimulated by $\mathrm{H}_{2}$ plus $\mathrm{CO}_{2}, \mathrm{H}_{2}$ plus $\mathrm{S}_{0}$ with or without $\mathrm{CO}_{2}, 0.3 \%$ (wt/vol) methanol, gelatin, or ethanol. The addition of $25 \mathrm{mM}$ threonine, 25 $\mathrm{mM}$ valine, $25 \mathrm{mM}$ phenylalanine, $25 \mathrm{mM}$ leucine, or $25 \mathrm{mM}$ isoleucine does not support, stimulate, or inhibit growth on medium containing $0.3 \%$ yeast extract and $0.25 \%$ (wt/vol) glucose.

The doubling times are between 45 and 55 min during growth on all carbohydrates except cellobiose, which yields a doubling time of $70 \mathrm{~min}$. With pyruvate the doubling time is 35 to $40 \mathrm{~min}$ at $\mathrm{pH} 7.0$ and $55^{\circ} \mathrm{C}$. The addition of up to 250 $\mathrm{kPa}$ of $\mathrm{H}_{2}$ to the head gas does not inhibit growth with sugars. As with $C$. thermocellum (7), a shift to more oxidized products and an increase in acetate production occur when $\mathrm{H}_{2}$ is continuously removed by flushing the headspace with argon.

Meat is not digested. Catalase is not produced. When the 
TABLE 1. Fermentation products from glucose and pyruvate by $C$. thermobutyricum

\begin{tabular}{|c|c|c|c|c|c|c|c|c|c|}
\hline \multicolumn{2}{|l|}{ Substrate(s) } & \multicolumn{6}{|c|}{ Concn of products formed $(\mu \mathrm{mol} / \mathrm{ml})$} & \multirow{2}{*}{$\begin{array}{l}\text { Carbon } \\
\text { recovery } \\
(\%)\end{array}$} & \multirow{2}{*}{$\begin{array}{l}\text { Ratio of oxidized } \\
\text { product to } \\
\text { reduced product }\end{array}$} \\
\hline Initial concn & $\begin{array}{l}\text { Amt utilized } \\
(\mu \mathrm{mol} / \mathrm{ml})\end{array}$ & $\mathrm{H}_{2}$ & $\mathrm{CO}_{2}$ & Butyrate & Lactate & Pyruvate & Acetate & & \\
\hline $\begin{array}{l}27.8 \mathrm{mM} \text { glucose }+0.3 \% \\
\text { yeast extract }\end{array}$ & 13.5 & 23.8 & 24.5 & 10.5 & 1.9 & & 1.0 & 91.6 & 1.09 \\
\hline $\begin{array}{l}27.8 \mathrm{mM} \text { glucose } \\
\text { yeast extract }\end{array}$ & 14.0 & 33.6 & 30.5 & 12.5 & 2.2 & 0.9 & & 106.9 & 1.03 \\
\hline $\begin{array}{l}71.9 \mathrm{mM} \text { pyruvate }+0.3 \% \\
\text { yeast extract }\end{array}$ & 49.8 & 17.9 & 52.5 & 17.4 & & & 15.4 & 102.3 & 1.02 \\
\hline $2 \%$ Yeast extract & 11.6 & 10.6 & 3.5 & 8.2 & & & $\operatorname{tr}$ & & $(1.14)^{a}$ \\
\hline $0.3 \%$ Yeast extract & 5.6 & 5.0 & 1.7 & & & & $\operatorname{tr}$ & & $(1.11)^{a}$ \\
\hline
\end{tabular}

${ }^{a}$ Since the redox state of the compound used from the complex medium is not known, the ratio does not need to be 1.00 .

An-Ident System (API Analytab Products, Plainview, N.Y.) is used for characterization, positive results are obtained at 30 and $45^{\circ} \mathrm{C}$ for L-glucosidase and arginine aminopeptidase. At both temperatures, the phosphatase reaction and gelatin hydrolysis give weak positive reactions. All of the following reactions are negative: ammonia production from arginine; casein hydrolysis; nitrate reduction; denitrification; indole production; $N$-acetylglucosaminidase; L-arabinosidase; betaglucosidase; L-fucosidase; L-galactosidase; beta-galactosidase; pyroglutamic acid arylamidase; indoxyl acetate reaction; leucine, proline, tyrosine, alanine, histidine, phenylalanine, and glycine aminopeptidases; and formate-plusfumarate utilization. Volatile fatty acids are not formed from valine, leucine, isoleucine, and phenylalanine $(0.1$ to $0.3 \%$, $\mathrm{wt} / \mathrm{vol}$; tested separately). However, $10 \mu \mathrm{mol}$ of propionate per $\mathrm{ml}$ of culture is formed from $0.3 \%$ (wt/vol) threonine.

Fermentation balance. The fermentation during growth on glucose in the presence of yeast extract can be represented by the following equation: glucose $\rightarrow 0.85$ butyrate +1.8 $\mathrm{CO}_{2}+1.9 \mathrm{H}_{2}+0.2$ lactate +0.1 acetate. Variations occur, especially with respect to the amount of acetate formed. When no acetate is produced, the molar yield of butyrate increases to $0.9 \mathrm{~mol}$ of butyrate per mol of glucose. In some experiments, up to $0.2 \mathrm{~mol}$ of acetate per mol of glucose is produced, and the butyrate yield deceases to $0.7 \mathrm{~mol}$ of butyrate per mol of glucose. Yeast extract has some influence on the fermentation balance (Table 1). In the absence of glucose but in the presence of $0.3 \%(\mathrm{wt} / \mathrm{vol})$ yeast extract, $1.7 \mu \mathrm{mol}$ of butyrate, $5.6 \mu \mathrm{mol}$ of $\mathrm{H}_{2}$, and $5.0 \mu \mathrm{mol}$ of $\mathrm{CO}_{2}$ are formed per $\mathrm{ml}$ of culture, along with traces of $\alpha$-hy- droxybutyrate, valerate, and propionate. These trace products also are found when cells are grown with carbohydrates or pyruvate. In the presence of $2 \%$ yeast extract, traces of pyruvate also are frequently observed.

Growth on pyruvate in the presence of $0.3 \%$ yeast extract can be represented by the following equation (Table 1): 3 pyruvate $\rightarrow 1.0$ butyrate $+3.0 \mathrm{CO}_{2}+1.0 \mathrm{H}_{2}+1.0$ acetate.

Susceptibility to antibiotics. $C$. thermobutyricum is not susceptible to cycloheximide, amphotericin B, actinomycin $\mathrm{D}$, and novobiocin at concentrations of $100 \mu \mathrm{g} / \mathrm{ml}$ of culture, but is susceptible to a variety of other antibiotics at concentrations of $5 \mu \mathrm{g} / \mathrm{ml}$ of culture (Table 2).

Maintenance. Viable stock cultures are prepared by mixing 1 volume of a logarithmically grown culture with 1 volume of anaerobic glycerol and storing the mixture in 5-ml serum vials closed with black butyl rubber stoppers at -18 or $-75^{\circ} \mathrm{C}$. After more than 2 years of storage, the inoculation of $0.2 \mathrm{ml}$ of stock culture into $10 \mathrm{ml}$ of fresh medium yields a turbid, actively growing culture in less than $8 \mathrm{~h}$. Sporulated cultures can be kept at $4^{\circ} \mathrm{C}$. They can be easily reactivated after 25 months by subjecting them to heat shock for $1 \mathrm{~min}$ at $100^{\circ} \mathrm{C}$.

Habitat. Type strain JW171K (= DSM 4928) was isolated from horse manure compost containing straw and wood shavings. Similar strains, (strains JW172 and JW173) were isolated at $55^{\circ} \mathrm{C}$ and $\mathrm{pH} 8.4$ from other horse manure piles near Athens, Ga. However, these strains have not been characterized in detail. They grow at $60^{\circ} \mathrm{C}$ but not at $65^{\circ} \mathrm{C}$ and produce butyrate as the major fermentation product from glucose. No other morphologically similar strains have been detected in enrichment cultures, under the same con-

TABLE 2. Antibiotic susceptibility of $C$. thermobutyricum

\begin{tabular}{|c|c|c|c|c|}
\hline \multirow{2}{*}{ Activity against: } & \multirow{2}{*}{ Antibiotic } & \multicolumn{2}{|c|}{$\begin{array}{l}\text { Inhibition of growth at } \\
\text { a concn of }{ }^{a}:\end{array}$} & \multirow[t]{2}{*}{ Bacteriostatic $^{b}$} \\
\hline & & $100 \mu \mathrm{g} / \mathrm{ml}$ & $5 \mu \mathrm{g} / \mathrm{ml}$ & \\
\hline \multirow[t]{2}{*}{ Cell wall synthesis } & Ampicillin & + & - & - \\
\hline & Bacitracin & + & - & - \\
\hline \multirow[t]{6}{*}{ Protein synthesis } & Chloramphenicol & + & - & - \\
\hline & Erythromycin & + & + & + \\
\hline & Tetracycline & + & + & + \\
\hline & Neomycin sulfate (B + C mixture) & + & + & - \\
\hline & Streptomycin sulfate & + & - & - \\
\hline & Kanamycin sulfate & + & - & - \\
\hline Cell membrane synthesis & Polymyxin B sulfate & + & + & + \\
\hline Nucleic acid synthesis & Metroimidazole (2-methyl-5-nitro-imidazole-1-ethanol) & + & + & $+^{a}$ \\
\hline
\end{tabular}

\footnotetext{
$a+$, Inhibition of growth; -, no difference in growth compared with control cultures. No inhibition was found with cycloheximide, amphotericin B, actinomycin D, and novobiocin at concentrations of $100 \mu \mathrm{g} / \mathrm{ml}$.

$b+$, Bacteriostatic (growth occurred after the culture was diluted 10 times). -, Bacteriocidal. Dilutions were made from cultures exhibiting no growth after 6 days of incubation.
} 
ditions, from various soil samples from near Athens, Ga., and from salt marshes near Sapolo Island, Ga.

Type strain. Type strain JW171K has been deposited with the Deutsche Sammlung von Mikroorganismen as strain under DSM 4928. Its description is identical to the description given above for the species, and its $\mathrm{G}+\mathrm{C}$ content is 37.0 $\pm 0.1 \mathrm{~mol} \%$ (as determined by a chemical method [17]).

Key differential tests. $C$. thermobutyricum is a thermophile and is differentiated from mesophilic clostridia by growth at temperatures above $55^{\circ} \mathrm{C}$. Although several of the thermophilic species have $\mathrm{G}+\mathrm{C}$ contents in the range of the $\mathrm{G}+\mathrm{C}$ content of this species $(37 \mathrm{~mol} \%)$, none of them produces butyric acid ( $C$. thermocellum, 38 to 40 mol\%; Clostridium thermohydrosulfuricum, 35 to $37 \mathrm{~mol} \%$; Clostridium thermosulfurigenes, $33 \mathrm{~mol} \%$; Clostridium stercorarium, $39 \mathrm{~mol} \%$ ). Among the validly published thermophilic clostridia, Clostridium thermosaccharolyticum $(\mathrm{G}+\mathrm{C}$ content, 29 to 32 mol\%) is the only species that produces butyrate as a major product. However, this organism can shift totally to ethanol formation, as reported by Landhuyt et al. (10), and also produces butanol (D. Freier, G. Gottschalk, and J. Wiegel unpublished data), properties which we have not observed for $C$. thermobutyricum. Thus, ethanol formation can be used as a differential test. Furthermore, the spore morphology differs markedly. C. thermosaccharolyticum forms a drumstick type of sporangium with distinct elongated thin cells, and the vegatative cells have a rectangular protein surface pattern, whereas $C$. thermobutyricum exhibits no regular surface pattern and forms subterminal spores that cause only a slight swelling. $C$. thermosaccharolytricum also differs with respect to pectin fermentation.

The combination of formation of butyrate as the major fermentation product from glucose and a $\mathrm{G}+\mathrm{C}$ content of 37 mol\% further distinguish $C$. thermobutyricum from other mesophilic species. Among clostridia, the formation of butyrate is widespread. Of more than 90 previously described species of Clostridium, nearly one-half produce butyrate as a major fermentation product in peptone-yeast extract-glucose medium, but only 20 form butyrate as the main product. However, in addition to butyrate, most species also produce significant amounts of other products, such as acetate, propionate, isobutyrate, isovalerate, isocaproate, lactate, ethanol, and butanol. C. thermobutyricum does not form ethanol, propanol, or butanol. Among the mesophilic and thermotolerant clostridia, there are only a few species that have $\mathrm{G}+\mathrm{C}$ contents of $37 \mathrm{~mol} \%$, the value for $C$. thermobutyricum. However, these species either do not produce butyrate as a major product or differ markedly in their morphology. Clostridium aceticum and Clostridium formicoaceticum have $\mathrm{G}+\mathrm{C}$ contents of 33 and $34 \mathrm{~mol} \%$, respectively, are mesophiles, have different morphologies, and produce no butyrate since they are homoacetogens. Clostridium aminovalerium has a $\mathrm{G}+\mathrm{C}$ content of $33 \mathrm{~mol} \%$, is a mesophile, and has a different morphology, and its main product is acetic acid. Clostridium innocuum has a $\mathbf{G}+\mathrm{C}$ content of $43 \mathrm{~mol} \%$, is a mesophile, has a different morphology, and does not convert threonine. Clostridium nexile has a $\mathrm{G}+\mathrm{C}$ content of $\mathbf{4 0} \mathrm{mol} \%$, is a mesophile, and does not form butyrate. Clostridium polysaccharolyticum has a $\mathrm{G}+\mathrm{C}$ content of $42 \mathrm{~mol} \%$, is a mesophile, utilizes cellulose, xylan, and starch, and forms formate as its main product. Furthermore, we found no indication that our strain is a thermophilic variant of any of the other mesophilic butyrateforming clostridia (3). Therefore, we conclude that we are justified in placing our strains in the new species $C$. thermobutyricum.

\section{ACKNOWLEDGMENTS}

We are indebted to W. B. Whitman and M. Mesbah for help with the $\mathrm{G}+\mathrm{C}$ determinations and $\mathrm{N}$. Weiss for the cell wall analysis. We also thank $\mathrm{H}$. Morgan for helpful discussions during the isolation of the organism and W. B. Whitman for help in editing the manuscript.

This work was supported by grant DE-FG09-86ER13614 from the Department of Energy to J.W.

\section{LITERATURE CITED}

1. Beuscher, N., F. Mayer, and G. Gottschalk. 1974. Citrate lyase from Rhodopseudomonas gelatinosa: purification, electron microscopy and subunit structure. Arch. Microbiol. 100:307-328.

2. Carreira, L. H., J. Wiegel, and L. G. Ljungdahl. 1983. Production of ethanol from biopolymers by anaerobic, thermophilic, and extreme thermophilic bacteria. I. Regulation of carbohydrate utilization in mutants of Thermoanaerobacter ethanolicus. Biotechnol. Bioeng. Symp. 13:183-191.

3. Cato, E. P., W. L. George, and S. M. Finegold. 1986. Genus Clostridium Prazmowski $1880,23^{\mathrm{AL}}$, p. 1141-1200. In P. H. A. Sneath, N. S. Mair, M. E. Sharpe, and J. G. Holt (ed.), Bergey's manual of systematic bacteriology, vol. 2. The Wiliams \& Wilkins Co., Baltimore.

4. Duong, T.-V., E. A. Johnson, and A. L. Demain. 1983. Thermophilic anaerobic and cellulolytic bacteria. Top. Enzyme Ferment. Biotechnol. 7:156-195.

5. Enebo, L. 1949. Symbiosis in thermophilic cellulose fermentation. Nature (London) 163:805.

6. Frasca, J. M., and V. R. Parks. 1965. A routine technique for double-staining ultrathin sections using uranyl and lead salts. J. Cell Biol. 25:157-161.

7. Freier, D., C. P. Mothershed, and J. Wiegel. 1988. Characterization of Clostridium thermocellum JW 20. Appl. Environ. Microbiol. 54:204-211.

8. International Journal of Systematic Bacteriology. 1985. Validation of the publication of new names and new combinations previously effectively published outside the IJSB. List no. 17. Int. J. Syst. Bacteriol. 35:224-225.

9. Kellenberger, E., A. Ryter., and J. Sechaud. 1958. Electron microscope study of DNA-containing plasma. II. Vegetative and mature phage DNA as compared with normal bacterial nucleoids in different physiological states. J. Biophys. Biochem. Cytol. 4:671-678.

10. Landhuyt, S. L., M. Lu, and E. J. Hsu. 1983. Transformation from acid fermentation to solvent fermentation in an chemostat of Clostridium thermosaccharolyticum. Ann. N.Y. Acad. Sci. 413:473-478.

11. Ljungdahl, L. G., and J. Wiegel. 1987. Anaerobic fermentations, p. 84-96. In A. L. Demain and N. A. Solomon (ed.), Manual of industrial microbiology and biotechnology. American Society for Microbiology, Washington, D.C.

12. McBee, R. H. 1950. The anaerobic thermophilic cellulolytic bacteria. Bacteriol. Rev. 14:51-63.

13. Möller, B., R. Ossmer, B. H. Howard, G. Gottschalk, and H. Hippe. 1984. Sporomusa, a new genus of gram-negative anaerobic bacteria including Sporomusa sphaeroides spec. nov. and Sporomusa ovata spec. nov. Arch. Microbiol. 139:388-396.

14. Spurr, A. R. 1969. A low-viscosity epoxy resin embedding medium for electron microscopy. J. Ultrastruct. Res. 26:31-43.

15. Valentine, R. C., B. M. Shapiro, and E. R. Stadtman. 1968. Regulation of glutamine synthetase. XII. Electron microscopy of the enzyme from E. coli. Biochemistry 7:2143-2152.

16. Venable, J. H., and R. A. Coggeshal. 1965. A simplified lead citrate stain for use in electron microscopy. J. Cell Biol. 25:407-408.

17. Whitman, W. B., S. Jersong, S. Sohn, D. S. Caras, and U. Premachandran. 1986. Isolation and characterization of 22 mesophilic methanococci. Syst. Appl. Microbiol. 7:235-240.

18. Wiegel, J. 1981. Distinction between the Gram reaction and the Gram type bacteria. Int. J. Syst. Bacteriol. 31:88.

19. Wiegel, J., and L. Quandt. 1982. Determination of the Gram type using the reaction between polymyxin B and lipopolysaccharides of the outer cell wall of whole bacteria. J. Gen. Microbiol. 128:2261-2270. 